Portland State University

PDXScholar

\title{
Using Satellite Observations to Characterize the Response of Estuarine Turbidity Maxima to External Forcing
}

\author{
Austin S. Hudson \\ Portland State University \\ Stefan A. Talke \\ Portland State University, talke@pdx.edu \\ David A. Jay \\ Portland State University, djay@pdx.edu
}

Follow this and additional works at: https://pdxscholar.library.pdx.edu/cengin_fac

Part of the Civil and Environmental Engineering Commons, and the Oceanography and Atmospheric Sciences and Meteorology Commons

Let us know how access to this document benefits you.

\section{Citation Details}

Hudson A.S., Talke S.A., Jay D.A. 2017. Using Satellite Observations to Characterize the Response of Estuarine Turbidity Maxima to External Forcing. Estuaries and Coasts, 40(2):343-358.

This Post-Print is brought to you for free and open access. It has been accepted for inclusion in Civil and Environmental Engineering Faculty Publications and Presentations by an authorized administrator of PDXScholar. Please contact us if we can make this document more accessible: pdxscholar@pdx.edu. 
Using satellite observations to characterize the response of estuarine turbidity maxima to external forcing Austin S. Hudson ${ }^{1 \dagger}$, Stefan A. Talke ${ }^{1}$ and David A. Jay ${ }^{1}$

${ }^{1}$ Department of Civil and Environmental Engineering

Portland State University

PO Box 751 - CEE

Portland, OR 97207

†email: hudsona@pdx.edu, phone: 801-707-9258

Keywords: Estuarine turbidiy maxima, remote sensing, MODIS, Columbia River Estuary

\section{Abstract:}

This study explores the spatial and temporal character of turbidity maxima in the Columbia River Estuary (CRE) using satellite observations. Surface reflectance data measured by the Moderate Imaging Spectroradiometer (MODIS) were calibrated against in situ measurements of surface turbidity $\left(R^{2}=0.85\right.$ for 205 measurements). More than 1,500 satellite images from 2000-2015 were then conditionally sampled to explore the physical processes that drive the spatial distribution of the turbidity field. We find satellite measurements are able to describe seasonal, spring-neap, and spatial features of the estuarine turbidity maxima (ETM) that are not easily observable by other means. System-wide levels of turbidity are most sensitive to river flow and spring-neap tidal range, with a weaker correlation to wind and waves. Maximum surface turbidity is observed in winter during elevated flow from coastal tributaries, and remains elevated during the spring freshet of the main stem Columbia. Two ETM with asymmetric alongchannel profiles are observed, one in the North Channel and another in the South Channel. Turbidity distributions migrate downstream as tidal range and river flow increase, but appear to become topographically trapped near topographic holes at river kilometer 15-20. Hence, depth-sensitive circulation processes like internal asymmetry and gravitational circulation are likely important mechanisms for trapping particles and determining ETM location. These conclusions confirm the 
31 theoretical result that along channel distributions of turbidity should have an 32 asymmetric distribution, and emphasizes the role of bottom topography. 


\section{3}

34

35

36

37

51 riverine, and wind forcing (Jay et al., 2015). Logistics and costs limit the spatial

52 resolution of in-situ sensors. Moreover, in-situ point data are inherently difficult to

53 interpret when large spatial variability is present, since it becomes difficult to 
54 separate vertical mixing processes from horizontal advection (i.e., the usual 55 assumption that advective transport is small breaks down when large spatial 56 gradients exist). To combat this deficiency, multiple studies starting with Postma 57 \& Kalle (1955) have analyzed the turbidity distribution measured from moving 58 ships (see also Kappenberg and Grabemann, 2001; Uncles et al., 2002; Talke et 59 al., 2009; de Jonge et al., 2014). While shipboard transects obtain better spatial 60 resolution than in-situ data, the measurements are often obtained over multiple 61 hours or even a day, especially in long estuaries (Talke et al., 2008). Spatial 62 measurements are therefore only quasi-synoptic and often occur at different tidal 63 phases, depth, and mixing conditions. Hence, interpretation of the spatial 64 distribution is affected or biased by ship travel time and temporal aliasing.

65 Satellite measurements offer an opportunity to address the limitations of 66 in-situ measurements by obtaining instantaneous snapshots of an estuary with 67 much higher spatial resolution. A number of studies have developed methods for 68 remotely measuring suspended sediment concentration (SCC) in estuarine 69 environments using the MODerate Imaging Spectroradiometer (MODIS) and 70 other satellite-based instruments (e.g. Ruhl et al., 2001; Doxoran et al., 2003, 71 2006, 2009; Lehner et al., 2004; Chen et al., 2006; Palacios et al., 2009). These 72 studies qualitatively link spatial patterns of turbidity to tidal, fluvial, and 73 atmospheric forcing, demonstrating the potential of satellites for monitoring ETM. 74 However, these studies have typically analyzed only a few images, possibly 75 because satellite measurements have a long return period (typically 1 day to two 
76 weeks) relative to tidal forcing and are affected by atmospheric conditions, such

77 that as few as $10 \%$ of images can be used. Hence, interpretation of results has

78 been qualitative and the potential of using satellite data to statistically

79 characterize estuarine turbidity has not yet been exploited. We address these

80 issues by applying a 'big data' approach and evaluating the entire 15year MODIS

81 record. After applying quality flags and retaining only good quality images, we

82 conditionally sample the resulting data set of $>1,500$ images to quantify the

83 effects of river discharge, greater diurnal tidal range, and wind forcing on the

84 turbidity field. A seasonally varying climatology is produced, and the relative

85 contributions of different tributary streams to turbidity variability are determined.

$86 \quad$ Beyond quantifying spatial statistics, satellite measurements may allow us

87 to investigate aspects of the along-channel turbidity distribution that have been

88 difficult to ascertain with ship-board measurements or in-situ sensors. For

89 example, Talke et al. (2008, 2009b) suggest that the longitudinal profile of an

90 ETM is inherently asymmetrical, due to the different forcing mechanisms (river

91 flow, estuarine circulation) which dominate transport on either side of the ETM.

92 Differences in the particle size distribution along the estuarine salinity gradient

93 may also cause asymmetry in the suspended sediment distribution between the

94 two sides of an ETM. Longitudinal profiles of the ETM have been measured, but

95 (as discussed above) such shipboard measurements are not truly synoptic.

96 Moreover, such longitudinal profiles may not adequately assess lateral variability 
97 in SSC. Hence, previously observed features in a turbidity field (such as multiple 98 surface ETM) could (in theory) be due to either unresolved lateral variability or 99 temporal variations in along-channel tidal forcing. In this study we analyze 100 instantaneous transects of surface turbidity in the Columbia River Estuary (CRE) 101 using satellite-based estimates to test the hypothesis that ETM are asymmetrical.

102 We also investigate the existence of multiple ETM, and examine the physical 103 mechanisms driving the turbidity distribution by monitoring the spatial and 104 temporal variability of the ETM.

105 Our investigation addresses the following questions: 1) what are the tidal, 106 fluvial, and seasonal patterns of ETM in the Columbia River Estuary? 2) are 107 multiple surface ETM visible from satellite data? 3) what is the shape of the ETM 108 under different conditions? and 4) which physical variables control ETM position 109 and shape? Since satellite data are synoptic they can reveal spatially resolved

110 features that cannot effectively be measured by either ship-based experiments or

111 existing moored observations. These spatial snapshots can then be compared to

112 theoretical descriptions of the turbidity distribution to reveal which mechanisms 113 control circulation and transport.

114

\section{$115 \quad 2.0$ Setting and Methods}

116 In the following section we detail the geophysical characteristics of the

117 Columbia River Estuary (Section 2.1), summarize data sources (Section 2.2), and 
118 describe how turbidity is obtained from satellite remote sensing data (Section 119 2.3).

\section{$120 \quad 2.1$ Site Characterization}

The CRE is a drowned river valley in which salinity intrudes from the ocean

122 into the lower estuary via two primary channels (North and South). These

123 channels are separated by sand flats and are bordered on their other side by either

124 coastline or large, shallow embayments. The estuary channels and subtidal flats

125 have a shallow aspect ratio, with depths rarely exceeding $15 \mathrm{~m}$. In this study the

126 system is divided into three regions (Fig. 1): The lower-estuary between river

127 kilometer (Rkm) 0-20, where saltwater is nearly always present and mechanical

128 energy is dominated by tidal and wave processes; A mid-estuary region (Rkm 20-

129 30) which typically exhibits the largest salinity gradients observed in the system;

130 and an upper-estuary region (Rkm 30-45) where salinity is often absent but

131 density gradients occasionally occur and affect the velocity field.

132 Tides are mixed (predominately semidiurnal) with an $\mathrm{M}_{2}$ amplitude that

133 varies by $\sim 10 \%$ in the estuary, with a peak of $0.95 \mathrm{~m}$ near Rkm 30 . Most of the

134 tidal energy is focused in the lower and mid-estuary, and begins decaying

135 upstream due to bed roughness and river flow, despite cross-sectional

136 convergence (Jay et al., 1990). The neap/spring cycle has a clear signal

137 throughout the year with greater diurnal tidal range ranging from 1.6 to $>3.6 \mathrm{~m}$

138 at Tongue Point. Tidal range is largest at the end of summer when the effect of 
139 river flow on tide wave propagation and attenuation is minimal (Jay, 1987; Jay,

140 1991; Chawla et al., 2007).

141 The Columbia is the largest Northeast Pacific river system, with a

142 watershed of $\sim 660,500 \mathrm{~km}^{2}$. It is the source of $60 \%$ to $90 \%$ of freshwater input to

143 the coastal ocean of Northern California, Oregon, and Washington (Pruter and

144 Alverson, 1972). River flow exhibits strong seasonal variability, with the largest

145 flows usually occurring during a May/June freshet. Much shorter winter freshets

146 are fed primarily by coastal tributaries such as the Willamette and Cowlitz Rivers,

147 while the smallest flows occur during late summer when precipitation and

148 snowmelt runoff are minimal (Fig. 2). The annual regime of river flow has been

149 dramatically altered by flow regulation, and to a lesser extent climate change over

150 the last century. Thus, contemporary spring freshet flows have been reduced by

$151 \sim 45 \%$ and occur about a month earlier than their early $20^{\text {th }}$ century counterparts

152 (Naik and Jay, 2010; Naik and Jay, 2011). This flow regulation has led to a

153 decrease in sediment input from the main stem Columbia River, and the CRE is

154 currently sediment-poor and erosional (Templeton and Jay, 2013).

155 The residual (tidally-averaged) estuarine circulation in the CRE is highly 156 variable in space and time (Hughes and Rattray, 1980; Jay and Smith, 1990a).

157 Irregular bottom topography (Fig. 3) augments spatial variability of the

158 circulation by locally enhancing estuarine circulation, producing along channel

159 convergences and divergences in the residual flow, and intensifying or reducing

160 vertical mixing (Jay and Smith, 1990a). The salinity field transitions from weakly 
161 stratified (most of the tidal month) to strongly stratified conditions during and 162 directly following neap tides (Jay and Smith, 1990b). Flushing times and 163 adjustments in the salinity field are relatively short ( $\sim$ few days) and nearly in 164 phase with the spring-neap cycle and fluvial regime (Jay and Smith, 1990a), 165 therefore, scalar concentrations react quickly to changes in river flow, tides, and 166 residual circulation.

167 Suspended sediment in the CRE is primarily of fluvial origin, composed 168 mostly of fines (silt and clay) and aggregates, except during large tides and river

169 flows when boundary shear stress is sufficient to suspend sands from the bed (Jay 170 et al., 1990; Sherwood and Creager, 1990). Fines are supply limited; the capacity

171 for transport is nearly always present and fine sediments will move whenever they

172 are available. Coarse sediment (sand and gravel), in contrast, is transport capacity

173 limited and there is an abundant supply that becomes mobile only under 174 appropriate flow conditions (Naik and Jay, 2011). Suspended sediment 175 concentration (SSC) is typically less than $100 \mathrm{gm}^{-3}$ throughout the CRE (Fain et al., 176 2001), a level much lower than in many other estuarine systems (Talke et al., 177 2009; Doxoran et al., 2009). However, depth-averaged ETM sediment 178 concentration can occasionally exceed $500 \mathrm{gm}^{-3}$ (Gelfenbaum, 1983).

179 Net sediment transport in the CRE is driven in part by tidally averaged 180 estuarine circulation induced by horizontal density gradients (Hansen and 181 Rattray, 1965; Festa and Hansen, 1978), and internal tidal asymmetry emerging 182 from tidal modulations of vertical mixing and stratification (Jay and Smith, 
183 1990a; Simpson et al., 1990; Jay and Musiak, 1996; Buchard and Baumert, 184 1998). Transport is also driven by tidal asymmetries in flow and mixing caused by 185 frictionally-produced overtides (Geyer, 1993; Jay and Musiak, 1994, 1996;

186 Burchard and Baumert, 1998; Chernetsky et al., 2010; Burchard et al., 2013).

187 Horizontal convergences in the residual and tidal sediment transport serve to trap 188 particles and form ETM, the magnitude and location of which depends on the 189 strength of the tides, river flow, stratification, and bottom topography (Geyer, 190 1993; Jay and Musiak, 1994; Burchard and Baumert, 1998; Schoellhamer, 2001;

191 Talke et al., 2008; Donker and de Swart, 2013).

192 ETM are found in both the North and South Channels of the CRE, in

193 locations that are close to the upstream limits of salinity intrusion (Jay and 194 Musiak, 1994; Fain et al., 2001), though topographic lows in each channel appear 195 to influence ETM position, as discussed below. The SSC in the ETM is up to ten 196 times greater than the fluvial supply (Gelfenbaum, 1983), though the residence 197 time of sediment varies from a few days to several months (Fain et al., 2001). A 198 third, more transient ETM has also been reported in association with the tidal 199 intrusion fronts and a topographic low at about Rkm-5.

\section{$200 \quad$ 2.2 Data Sources and Processing}

201 Satellite data used in this study are derived from surface reflectance 202 measurements made by MODIS. Two versions of this instrument sample the CRE 203 about 2 hours apart near midday aboard the AQUA (2002 to present) and TERRA 
204 satellites (2000 to present). Data are available at various processing levels, 205 ranging from raw data (Level-0) to highly processed end-products (Level-3). 206 Following Doxaran et al., 2009, a Level-2 swath product (MOD09) processed by 207 the Level 1 and Atmosphere Archive and Distribution System (LAADS; 208 https://ladsweb.nascom.nasa.gov/) was used in this study. MOD09 is 209 atmospherically corrected and includes state and quality datasets that flag pixels 210 with clouds or cloud shadows, high or low aerosol concentrations, or that cover 211 land, and mark poor quality measurements. These flags were used to filter out 212 measurements that incorrectly represent the state of the water surface. Remote 213 turbidity estimates were calibrated using measurements from MODIS Band 1 $214(620-670 \mathrm{~nm})$ at a $250 \mathrm{~m}$ resolution (Fig. 1), chosen to resolve gradients in the 215 estuary as well as possible.

216 In situ measurements of turbidity and salinity were derived from thirteen 217 stationary buoys (Table 1 and 2; Fig. 1) managed by the Center for Coastal 218 Margin Observation and Prediction (CMOP; http://www.stccmop.org/datamart/). 219 Turbidity observations used in this study were recorded intermittently from 2008 220 to 2015 (Fig. 4) at sub-minute intervals using WETLab's ECO FLNTU (measuring 221 at $\sim 700 \mathrm{~nm})$ or Turner Designs' Cyclops 7 (620-715nm) fluorometers. Salinity 222 measurements are available intermittently at various locations from 2003 to 2015. 223 At each location, turbidity measurements are made within 2.5 meters of the water 224 surface. Data from the Saturn 01 profiling system in the North Channel (Table 1; 
225 Fig.1) were conditionally sampled and averaged over the top $2 \mathrm{~m}$ of the water 226 column.

227 Surface and near bed salinity measurements at Saturn 01 in the North 228 Channel (2008-2015) and Saturn 04 in the South Channel (2009-2015) were 229 used to calculate salinity stratification. The along-channel salinity profile in the 230 South Channel was parameterized using a hyperbolic tangent function, using a 231 least squares fit of a hyperbolic tangent curve to salinity data following Warner et 232 al. (2005) and Talke et al. (2009):

$$
S(x)=0.5 S_{o}\left(1-\tanh \frac{x-x_{c}}{x_{L}}\right)
$$

234 where $S_{o}$ is the ocean salinity, and $x_{L}$ and $x_{c}$ are parameters that scale the salinity 235 gradient and mark its maximum location, respectively. A least-squares approach 236 was applied to estimate $x_{c}, x_{L}$, and $S_{o}$, for near bed measurements (data from 2003 237 to 2010) and near surface measurements (data from 2003 to 2006) to construct a 238 salinity profile. The along-channel coordinate with 2 psu salinity was then used as 239 marker for salinity intrusion. Data in the North Channel were too sparse to allow 240 estimation of salinity intrusion.

241 Factors that affect turbidity include river discharge, tidal range, wind speed 242 and direction, and ocean swell. These data are obtained from the USGS (United 243 States Geological Survey) and NOAA (National Oceanic and Atmospheric 244 Administration) and were recorded at various locations throughout the CRE 
245 (Table 3). River flow was processed as daily averages and all other measurements 246 as hourly averages. Ocean swell was defined as the integrated spectral energy at 247 frequencies $<0.1 \mathrm{~Hz}$ (period $\mathrm{T} \geq 10$ seconds), while wind-speed was separated 248 into two time series according to wind direction to take into account the effect of 249 wind direction on wave fetch, following the approach of Talke and Stacey (2003). 250 One wind-speed time series consisted of wind blowing along the estuary axis from 251 the west northwest (typical for summer conditions), while the other consisted of 252 wind blowing from the east southeast, more typical of winter conditions.

253 The forcing variables—wind, waves, tides, and river discharge-were then 254 regressed against MODIS-based surface turbidity estimates (described below) to 255 determine the spatial zones of influence for each forcing variable. Other forcing 256 variables are held approximately constant during each regression via a binning 257 approach, to minimize the possibility that correlations are driven by another, 258 jointly correlated process (such as seasonal changes in flow, wind, and tidal 259 range). For example, we test the effect of wind direction and wave energy on 260 turbidity by requiring that greater diurnal tidal range and river flow be in the 261 range $2.5+/-0.5 \mathrm{~m}$, and $5500 \mathrm{~m}^{3} \mathrm{~s}^{-1}+/-1500 \mathrm{~m}^{3} \mathrm{~s}^{-1}$, respectively. These bin sizes are 262 a compromise between holding forcing variables constant, to first order (20-30\% 263 deviation from mean), while retaining enough samples to remain statistically 264 significant. To account for the observation that erosion must occur over a critical 265 stress, we further process the wind series by considering only wind-speeds above a 266 threshold. While empirical studies at other locations find a wind threshold of $\sim 5$ - 
$2676 \mathrm{~ms}^{-1}$ for local erosion (e.g., de Jonge and van Beusekom, 1995; Christie et al., 268 1999), we find that a lower threshold of $2 \mathrm{~m} / \mathrm{s}$ obtains reasonable results while 269 retaining a statistically significant sample size. The low threshold likely results 270 from the presence of large mid-estuary flats and extensive peripheral bays. While 271 the mid-estuary flats are primarily sand-bedded, they can temporarily retain fines 272 (Sherwood and Craeger, 1990).

\section{$273 \quad 2.3$ Remote sensing of turbidity}

274 Satellite-based instruments record Top of the Atmosphere (TOA) radiation, 275 which is converted to surface reflectance (the ratio of reflected/backscattered 276 radiance to incident solar irradiance) by adjusting raw measurements for solar 277 and sensor zenith angles, gaseous and aerosol scattering and absorption, 278 adjacency effects, and cloud contamination (cf. Vermote and Vermeulen, 1999).

279 Surface reflectance is measured in discrete frequency bands that correspond to 280 peaks in the reflectance of various optically active constituents (OACs), such as 281 suspended sediment or chlorophyll-a. Since the optical properties (e.g. absorption 282 and backscatter spectra) of OACs change with concentration and significantly 283 alter the measured reflectance signature (Bricaud et al., 1981; Bricaud et al., 284 1995; Neukermans et al., 2012), a relationship between satellite and in situ data 285 can, in principle, be established.

286 Calibration of remote-based measurements of OACs is carried out by 287 empirical or semi-analytical algorithms. Semi-analytical algorithms are based on 
288 modeling radiative transfer phenomena and rely on the deconvolution of the 289 measured reflectance spectrum of a water body into individual OAC 290 concentrations (Maritorena et al., 2002; IOCCG, 2006). By contrast, empirical 291 algorithms rely on statistical correlations between remote and in situ data. They 292 often involve band arithmetic formulae and have been successfully applied in 293 various estuarine systems (Doxaran et al., 2003, 2006, 2009; Hu et al., 2004; 294 Chen et al., 2006). Since OAC optical properties are not fully characterized in the 295 CRE, semi-analytical methods applied to the Oregon coast typically fail in the 296 estuary (Palacios et al., 2009). Therefore, we use an empirical model to derive 297 satellite-based estimates of CRE surface turbidity.

298 The empirical model of surface turbidity was calibrated using a total of 205 299 concurrent measurements of turbidity and cloud-free surface reflectance during 300 the observation period. To remove noise and small scale variability, in situ 301 measurements were averaged over a 5-min period centered at the time of each 302 satellite passing. MODIS data with a Band 2 to Band 1 ratio $>0.8$ were excluded 303 in the analysis. Ratios $>0.8$ correspond to land and cloud pixels missed in the 304 MOD09 processing, and proved useful for screening pixels which overlapped the 305 shoreline and exposed sand flats.

306 MODIS and in situ data are significantly correlated $\left(\mathrm{R}^{2}=0.85\right.$, error 307 variance $=1.25 \mathrm{ntu}$; Table 4 and Fig. 5), a relationship that most likely exists due 308 to the proximity of the MODIS Band 1 spectral range $(620-670 \mathrm{~nm})$ and the 
309 detection wavelength of the in situ turbidity sensors $(\sim 700 \mathrm{~nm})$. Experimentation

310 showed that a linear combination of Band 1 and Band 2 correlated slightly better

311 with in situ data. Because this difference was not statistically significant, we use

312 the simpler model based on Band 1 only (Equation 2 and Table 4). This

313 calibration was then applied to more than 1,500 images with good quality flags

314 from the years 2000-2015.

315

$$
\text { Turbidity }=0.59+137 *[\text { surface reflectance }] \quad \text { (Equation 2) }
$$

317 Many sources of error can degrade the relationship between MODIS and in 318 situ data, including (but not limited to) atmospheric scattering, the presence of 319 other OACs, the disparity between the in situ and remote detection wavelengths, 320 reflectance off the bed in shallow regions, and land contamination for pixels near 321 the shoreline. Furthermore, inherent differences in instrumentation and 322 processing may also lead to errors in the model. Buoy observations are a point 323 measurement that may not accurately assess spatial variability, whereas MODIS 324 integrates variability in the top portion of the water column over a $250 \mathrm{~m}$ by $250 \mathrm{~m}$ 325 area. Stratification in the water column, which is prevalent in the CRE, may 326 augment depth-related discrepancies. However, the generally low error variance 327 suggests that the sources of error described above do not significantly influence 328 results within the turbidity maximum zone. 
330 a can also produce errors. Because primary production in the CRE is relatively low 331 and the local food chain is predominantly detritus-based (Simenstad et al., 1990), 332 we assume here that the most significant contribution to surface reflectance is 333 suspended sediment. SSC obtained from spot water samples by the USGS at 334 Beaver Army Terminal (Rkm 86) from 2010 to 2014 shows good agreement with 335 in situ turbidity measurements made at the Saturn 05 station across the channel 336 (data not shown; $\mathrm{R}^{2}=0.88, \mathrm{~N}=21$ ); hence, the assumption that surface 337 reflectance and turbidity are dominated by suspended sediment (and not 338 chlorophyll) appears appropriate to first order.

339 While we use estimates of turbidity as a proxy for sediment concentration, 340 interpretation of in-situ and remote turbidity estimates may be confounded by 341 particle size variability in time and space. Since increased bed stresses during 342 large tides and periods of strong current suspend larger particles from the bed, 343 and since aggregation processes vary within an ETM and with tidal phase (Reed 344 and Donovan, 1994), turbidity/sediment calibrations which are sensitive to 345 changes in particle size can undermine analysis of ETM behavior. Jay et al. (1999) 346 found that calibrations of suspended particulate matter against acoustic 347 backscatter varied over the tidal cycle in the CRE in response to changing 348 scattering properties of different sized material. Nonetheless, Neukermans et al. 349 (2012) found that WET labs optical sensors are driven to first order by particle 
350 concentrations, with a weaker, second order dependence on particle size.

351 Although this observation gives confidence in our calibration and interpretation of

352 results, further research is required to definitively link sediment concentrations to

353 our satellite-based turbidity estimates.

354

355 3.0 Results and Discussion

356 Next we analyze seasonal patterns (Section 3.1) and along-channel

357 distributions of MODIS-based surface turbidity (Section 3.2) in relation to 358 external forcing variables.

\section{3.1 Seasonal Turbidity Distribution}

MODIS-based estimates of surface turbidity display a high degree of

361 temporal and spatial variability. Four basic system states are shown in Fig. 6: low

$362\left(3,800 \mathrm{~m}^{3} \mathrm{~s}^{-1}\right)$ vs high $\left(12,000 \mathrm{~m}^{3} \mathrm{~s}^{-1}\right)$ river flows during moderate tidal ranges (Fig.

$3636 \mathrm{a}$ and $\mathrm{c}$ ), and neap $(1.8 \mathrm{~m})$ vs spring $(3.5 \mathrm{~m})$ tides during low river flow (Fig. $6 \mathrm{~b}$

364 and d). As the source of most of the suspended sediment in the system (Jay et al.

365 1990), river flow has a direct relationship with surface concentrations throughout

366 the estuary. Dependence on the neap/spring cycle is also apparent; greater

367 concentrations are observed during spring tides when the larger tidal velocities

368 mix sediment from the bed to the surface.

369 Monthly averaged turbidity fields in the estuary (Fig. 7) exhibit

370 considerable seasonal variability during the study period; hence, the seasonally 
371 changing supply of sediment from the rivers is likely important. Maximum system 372 wide concentrations are observed in January and December during the winter 373 rainy season, when considerable flow is input from tributaries west of the Cascade 374 mountain range (daily average of $\sim 2,000 \mathrm{~m}^{3} \mathrm{~s}^{-1}$; Fig. 2); i.e., from the Coastal Sub375 basin (Fig 1.; Naik and Jay, 2011). Elevated turbidity levels persist throughout the 376 spring freshet in May and June, with river flow measured at The Dalles averaging $377 \sim 8,000 \mathrm{~m}^{3} \mathrm{~s}^{-1}$ and fed primarily by snow-melt in the Interior Sub-Basin. Both 378 interior and coastal river flows subside during the summer dry season, reaching a 379 minimum in September. The satellite-based climatology of turbidity (Fig. 7) is 380 consistent with studies that show in situ sediment concentrations vary by a factor 381 of 3 to 4 seasonally and up to ten spatially (Gelfenbaum, 1983; Sherwood and 382 Creager, 1990; Fain et al., 2001). Fig. 7 also suggests that the spatial distribution 383 of monthly averaged turbidity is relatively constant and less variable than 384 seasonal changes in concentration. Large gradients in the turbidity field are 385 always present in the lower/mid-estuary, while gradients in the upper-estuary 386 are more muted.

387 Coastal turbidity patterns also exhibit seasonal variability. During winter 388 months a large coastal plume deflects northwards, consistent with in-situ studies 389 (Horner-Devine et al., 2009; Hickey et al., 2010) and the prevailing wind 390 direction (see also Fig. 6). In upwelling conditions marked by northwesterly 391 winds, the average turbidity is spread more symmetrically around the CRE mouth 
392 (e.g., June and July). During parts of the year (e.g., September), some estimates 393 are below the noise-floor (the error variance of the empirical model is $1.25 \mathrm{ntu}$; 394 Table 4) and results are inconclusive.

395 The factors controlling the turbidity distributions in Fig. 6 and Fig. 7 are 396 examined by correlating time series of river discharge, greater diurnal tidal range, 397 estuarine wind speed, and offshore wave energy with corresponding estimates of 398 surface turbidity at each pixel location (p-value $\leq 0.01$ ). Results suggest that 399 turbidity is significantly correlated with along channel, summer wind-speed $400\left(>2 \mathrm{~ms}^{-1}\right)$ in shallow regions such as the mid-estuary sand flats, Young's Bay, and 401 Cathlamet Bay (correlation coefficient, R 0.2-0.4; Fig 8a). Winter wind-speed 402 correlates with surface turbidity in the mid-estuary and Young's Bay as well, but 403 also in Baker Bay (Fig 8b; see Fig. 1 for place-names). The differences between 404 summer and winter turbidity patterns in shallow water likely stem from seasonal 405 differences in prevailing wind direction, fetch, and therefore local wave forcing. 406 Winter winds primarily come from the east-southeast, and therefore have a larger 407 influence on turbidity in Baker Bay. By contrast, summertime winds are primarily 408 west-northwesterly, such that their influence is concentrated along southern 409 regions in the CRE. Note that although white-capping of wind-driven waves may 410 influence the surface reflectance signal, evaluation of in situ data at Saturn 07 in 411 Baker Bay confirm that turbidity increases during large wind events $(\mathrm{R} \sim 0.5$, $412 \mathrm{~N}>2,000)$. 
414 surface turbidity estimates at the mouth of the CRE near the jetties (R 0.4; Fig.

415 9), although we cannot evaluate whether the signal is due to white-capping from

416 wave breaking, turbidity, or both. Nonetheless, we observe that the elevated

417 MODIS reflectance at the jetties is consistent with observations that suggest that

418 wave-induced erosion is an important factor in jetty evolution (e.g. Hickson and

419 Rodolf, 1950; Elias et al., 2012). Unlike other estuaries (e.g., Talke and Stacey,

420 2008), the effect of ocean swell on turbidity cannot be statistically shown beyond

421 the entrance, though some low-frequency wave energy likely propagates inland 422 and to Baker Bay.

423 Greater diurnal tidal range, defined here as the difference between the 424 daily maximum and minimum tidal elevations, is significantly correlated with 425 turbidity throughout the system (median $\mathrm{R} \sim 0.36$; Fig. 10). Since tidal currents 426 increase during periods with large tidal range (spring tides), vertical eddy 427 viscosity increases, stratification is reduced, and more sediment is mixed to the 428 surface (Allen et al., 1980; Jay and Smith, 1990a). The correlation between 429 greater diurnal tidal range and turbidity is maximal in mid-estuary, where tidal430 monthly variations in stratification and ETM concentration are greatest 431 (Gelfenbaum, 1983; Jay and Smith, 1990a). The greater diurnal tidal range also 432 shows a positive relationship with turbidity in the coastal ocean, consistent with 433 previous studies that suggest more sediment is exported to the coast during spring 434 tides when vertical mixing is amplified (Jay et al., 2007; Fain et al., 2001). 

438 flow at the mouth (Orem, 1968) and includes both the main stem Columbia and 439 most major coastal tributaries, shows a median R of 0.51 over the estuary (Fig. 440 11). We find, however, that different tributaries exhibit statistically distinct 441 influences on the CRE turbidity. Coastal tributaries such as the Willamette (lagged 442 by 1 day) and the Cowlitz (lagged by 1 day) exhibit a dominant influence within 443 the estuary, with median $\mathrm{R}$ of 0.71 and 0.63 respectively. The main stem 444 Columbia River (measured with a 2 day lag from The Dalles) exhibits a much 445 lower correlation within the estuary (median $\mathrm{R}$ of 0.29 ), despite carrying an 446 average of $75 \%$ of the total annual discharge.

447 Despite its weaker effect on surface turbidity levels, main stem Columbia 448 River discharge is evidently large enough in May/June to make a significant 449 impact on overall turbidity levels (Fig. 2; Fig. 7); during this period, the discharge 450 from coastal tributaries is relatively small. The relatively weak correlation 451 between surface turbidity and main stem discharge is likely augmented by a 452 combination of the main stem sediment supply (see below) and stratification 453 during the Columbia River freshet that damps vertical mixing and therefore the 454 observed surface signal. Moreover, the larger river discharge in May/June exports 455 significant quantities of sediment to the shelf (Spahn et al., 2009), by increasing 456 seaward advection, reducing the salinity containing volume of the estuary that 
457 can trap sediment, lowering the trapping efficiency (which is inverse to supply 458 concentration), and decreasing suspended sediment residence time (Fain et al., 459 2001). Jay et al. 2007 provides a more complete discussion.

460 The influence of coastal tributaries, which are primarily driven by winter 461 storm events (rain and sometimes rain-on-snow), helps explain why the largest 462 turbidities are observed during winter (Fig. 7). Analysis of US Geological Survey 463 water quality data and sediment concentration data indicate that the Willamette 464 River sediment load typically has a higher percentage of fine sediment (with a 465 strong influence on surface turbidity) than the load from the main stem (Naik and 466 Jay, 2011). Wind may also play a role in enhancing winter-time turbidity (Fig. 8). 467 The observed influence of different tributaries on CRE turbidity is 468 consistent with local geology but is strongly influenced by the reservoir system 469 (Naik and Jay, 2010, 2011). As discussed by Gates (1994), the Lower Columbia 470 River is thought to have been historically sediment poor, possibly because late 471 Pleistocene floods scoured much of the Columbia River Basin. By contrast, coastal 472 tributaries such as the Cowlitz and Willamette carry runoff from regions with 473 active volcanoes and fine alluvium and aeolian deposits (Thesien, 1958; Balster 474 and Parsons, 1968). The Cowlitz, which drains the Mt St. Helens watershed, has 475 historically discharged large amounts of sediment to the CRE (Sherwood et al., 476 1990; Sherwood and Creager, 1990) and USGS measurements suggest elevated 477 suspended sediment concentrations related to the eruption in May 1980 persist to 478 this day (data not shown). Local development and land use practices may also 
479 affect coastal tributaries like the Willamette (Lyons and Beschta, 1983; Naiman et 480 al., 1992; Benner and Sedell, 1997; Norman et al., 1998). Since 1937 and 1941, 481 dams in both the Columbia and Willamette River Basins have increasingly 482 curtailed sediment export (Naik and Jay, 2011; Templeton and Jay, 2012; Wentz 483 et al., 1998). However, the high correlation of turbidity with the Willamette 484 hydrograph suggests that significant amounts of turbidity enter the system during 485 coastal storm events. Because the Willamette and Cowlitz may also act as a proxy 486 for smaller, unregulated coastal streams, we conclude that coastal tributaries 487 generally are important sources of suspended sediment exported to the estuary 488 and the coastal ocean.

$489 \quad 3.2$ Turbidity Transects We next examine the longitudinal distribution of turbidity along the North 491 and South Channels as defined in Fig. 1. Example transects are shown during 492 low/high flows $\left(3,000 \mathrm{~m}^{3} \mathrm{~s}^{-1}\right.$ and $11,000 \mathrm{~m}^{3} \mathrm{~s}^{-1}$ with $500 \mathrm{~m}^{3} \mathrm{~s}^{-1}$ window; Fig. 12a,b) 493 and neap/spring tides ( $2.0 \mathrm{~m}$ and $3.5 \mathrm{~m}$ with $0.15 \mathrm{~m}$ window; Fig. $12 \mathrm{c}$,d). Note that 494 transects exhibit variance around the median (illustrated by the $33^{\text {rd }}$ and $67^{\text {th }}$ 495 quantiles as shaded regions in Fig. 12), which is a result of inherent variance of 496 environmental conditions within the bin window and possibly uncorrected 497 atmospheric artifacts in remote measurements. Tidal excursion of the ETM 498 ( $\sim 20 \mathrm{~km}$; Gelfenbaum, 1983) and time varying mixing also contribute to the 499 variance because individual transects are observed during different tidal phases. 
500 Since a large number of data are concatenated in each bin $(>50)$, we argue that

501 the median curves in Fig. 12 approximate the tidally averaged turbidity

502 distribution for each greater diurnal tidal range/river flow combination.

503 3.2.1 Asymmetry in Turbidity Transects

504 The MODIS-based turbidity transects show that turbidity distributions are

505 typically asymmetrical, with larger gradients observed downstream of the

506 maximum. For example, gradients of $\sim 0.3 \mathrm{ntu} \mathrm{km}{ }^{-1}$ are observed downstream of

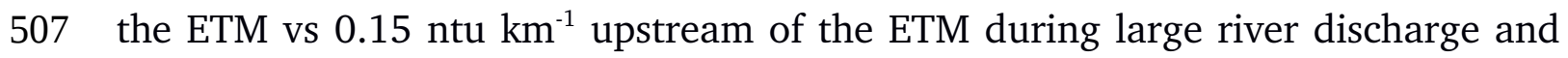

508 large tides in the South Channel (Fig. 12). These observations qualitatively agree

509 with theoretical studies of ETM behavior, which suggest that asymmetry can

510 develop because different physical processes dominate sediment transport on

511 either side of the maximum (Talke et al., 2008, 2009b). Landward of an ETM,

512 upstream sediment fluxes are small and the turbidity distribution is set by factors

513 such as river flow, dispersion, tidal pumping, and channel convergence. By

514 contrast, the turbidity distribution seaward of the ETM is controlled by the same

515 factors that produce the salinity field (Talke et al., 2008), resulting in similar

516 longitudinal length scales of variation (e.g., as encapsulated in Equation 1). The

517 relationship between salinity and turbidity scales is observed in MODIS-based

518 transects in the South Channel (Fig. 12d); during the transition from spring to

519 neap, both the near-bed salinity field and the ETM move landward (increasing $x_{c}$

520 in Equation 1) and become stretched over a larger distance (increasing $x_{l}$ in 
521 Equation 1). High flow conditions (Fig. 12b) exhibit increased gradients in both 522 the salinity and turbidity fields downstream of the ETM.

523 Asymmetry in surface turbidity during high flow conditions can be

524 quantified by fitting a hyperbolic tangent curve to either side of the ETM (similar 525 to Equation 1 for the salinity field). Results confirm that asymmetry is especially 526 prominent during high river flows as the ETM region approaches Rkm 15 in the 527 North Channel and Rkm 20 in the South Channel (Fig. 12a,b); turbidity gradient 528 lengthscales $\left(x_{L}\right)$ are 4 to 5 times greater upstream of the ETM than downstream

529 (Table 5). Because these locations have local depth maxima (Fig. 3) and landward 530 sediment fluxes are enhanced with increasing channel depth (Talke et al., 2009b; 531 de Jonge et al., 2014), topographic features may contribute to observed 532 asymmetry.

\section{3.2.2 Response of ETM to River flow and tidal forcing}

534 The response of ETM magnitude and position to forcing data is examined 535 with bin-median transects in the river flow $\left(1,000 \mathrm{~m}^{3} \mathrm{~s}^{-1}\right.$ window) and greater 536 diurnal tidal range $(0.25 \mathrm{~m}$ window) parameter space (Figure 13$)$. In both the 537 North and South Channels, the magnitude of the ETM $\left(C_{\max }\right)$ is a function of 538 greater diurnal tidal range and river flow. Surface $C_{\max }$ increases by a factor of $2-3$ 539 when flow rate increases from $2,500 \mathrm{~m}^{3} \mathrm{~s}^{-1}$ to $10,000 \mathrm{~m}^{3} \mathrm{~s}^{-1}$ (Fig. $12 \mathrm{c}$ and d), with 540 the largest increase occurring during neap tide conditions (Fig. 13). For the 541 largest river discharge bin with extensive data available $\left(10,000 \mathrm{~m}^{3} \mathrm{~s}^{-1}\right), C_{\max }$ is 
542 approximately constant regardless of greater diurnal tidal range. By contrast, 543 turbidity values approximately double when tide range increases from 2 to $3.5 \mathrm{~m}$

544 during low flow conditions $\left(<5,000 \mathrm{~m}^{3} \mathrm{~s}^{-1}\right)$. These observations are consistent with

545 the hypothesis that local resuspension and mixing processes dominate sediment

546 concentration magnitudes during low river discharge, but that external sediment

547 input from the river dominates estuarine sediment concentrations during large

548 discharge events. We note that the background river turbidity of about 2 NTU

549 during low discharge conditions (e.g., measured at Saturn 05 at Rkm 86) is

550 significant relative to estuary conditions, and may contribute to the observed $C_{\max }$,

551 particularly upstream of Rkm 40, where channel width converges and salinity is

552 generally absent. The dilution of river water downstream of Rkm 40 during low

553 discharge conditions (as measured by increasing salinity) may therefore

554 contribute to the overall longitudinal profile observed in Fig. 12b, in which no

555 clear maximum is observed and turbidity decreases all the way to the ocean 556 boundary.

557 The location of the ETM $\left(X_{\max }\right)$ in the North Channel is fairly stable, 558 between $\mathrm{Rkm} 20-25$, for a majority $(\sim 55 \%)$ of river discharge and tidal 559 conditions (Fig. 13a). The possible exception is non-neap tides during low river 560 discharge, in which $X_{\max }$ switches to an upstream locus between Rkm 25-30 (Fig.

561 12a and 13a). However, as shown in Fig. 12a, the statistical significance of the 562 upstream movement is somewhat ambiguous. Since the $\sim 10 \mathrm{~km}$ range over which 
$563 X_{\max }$ varies and turbidity is elevated is much smaller than the tidal excursion we 564 conclude that the tidally averaged position of the North Channel turbid zone or 565 ETM is relatively fixed for all conditions, at least to within the accuracy of our 566 estimate.

$567 X_{\max }$ in the South Channel is also found near Rkm 20-25 for a large 568 proportion (49\%) of the river discharge and tidal range parameter space. 569 Interestingly however, $X_{\max }$ exhibits a different dependency on tidal forcing in the 570 South Channel than in the North Channel, and is found further upstream (Rkm 571 30-35) as tidal range increases. During neap tides, reduced vertical mixing and 572 higher stratification result in increased salinity intrusion and landward sediment 573 transport (Gelfenbaum, 1983; Jay, 1990a; Talke et al., 2009); similarly, reduced 574 river flow results in the upstream movement of salinity and turbidity (Fig. 12). 575 The South Channel $X_{\max }$ location is especially sensitive whenever tidal ranges are 576 close to $2.7 \mathrm{~m} ; X_{\max }$ decreases by $5 \mathrm{~km}$ as tidal range exceeds $2.7 \mathrm{~m}$ for nearly all 577 river discharges (Fig. 13b).

578 The location of the surface ETM is influenced by the stratification and 579 mixing within the system and responds in concert with the salinity field to forcing 580 data (Fig. 12). During spring tides, tidally averaged South Channel salinity 581 intrusion (marked by the 2 PSU isohaline $X_{2}$ ) differs by $<3 \mathrm{~km}$ at the surface and 582 bed (Fig. 12d; compare positions of pink square and circle). Under these 583 conditions $X_{\max }$ is downstream of the near bed $X_{2}$ and occurs near the 8psu 
584 contour. By contrast, surface and bottom $X_{2}$ are separated by $\mathrm{O}(10 \mathrm{~km})$ during 585 neap tide conditions (Fig. 12d), indicating a strained salinity field and increased 586 stratification. $X_{\max }$ is shifted landward of $X_{2}$ in this case and occurs near the $1 \mathrm{psu}$

587 contour. For intermediate greater diurnal tidal ranges, South Channel $X_{\max }$ 588 exhibits a behavior in-between the spring and neap extremes for both small and 589 large discharge (Fig. 12b).

590 3.2.3 Comparison of North and South Channels; Topographic 591 trapping

592 The North and South Channels exhibit different reactions to increased river 593 discharge. While the South Channel salinity field and zone of stratification moves 594 downstream $10-15 \mathrm{~km}$ as river discharge increases (Fig. $12 \mathrm{~b}$ and $14 \mathrm{c}, \mathrm{d}$ ), the North 595 Channel remains stratified at Rkm 16 for all but the largest discharge conditions $596\left(>15,000 \mathrm{~m}^{3} \mathrm{~s}^{-1}\right.$; Fig. 13a,b). This behavior occurs both because the North Channel 597 receives less river discharge (Jay and Smith, 1990) and is thus less sensitive to 598 changing flow conditions, but also because of the topographic holes at Rkm 16 599 and Rkm 25 (Fig. 3) that trap saline water. Vertical mixing at Rkm 16 in the 600 North Channel is thus nearly always inhibited to some degree, resulting in 601 decreased surface turbidity compared to locations upstream. Strong stratification 602 at Rkm 16 also implies vigorous landward bottom currents due to gravitational 603 circulation (MacCready, 2007) and internal asymmetry (Jay, 2010), both of which 604 scale as $H^{2}$ and strongly affect the ETM position (Jay, 2010; Talke et al., 2008; 
605 Hudson, 2014). The decrease in depth from $\sim 16 \mathrm{~m}$ to $\sim 10 \mathrm{~m}$ on either side of 606 Rkm 16 implies a two-fold alteration in upstream circulation over a small distance 607 (not accounting for altered eddy diffusivity), and is a barrier to downstream 608 sediment transport. The South Channel salinity and turbidity fields are much 609 more sensitive to altered river discharge than the North Channel, but also exhibit 610 evidence of persistent turbidity gradients downstream of the topographic holes at 611 Rkm 20 during most flow and tidal conditions (Fig. 12b,d).

612 The scaling of estuarine circulation with depth supports the notion that 613 trapping of turbidity occurs due to circulation patterns related to topography 614 i.e., due to "topographic trapping". To demonstrate this idea, we note that two 615 features of the turbidity field are associated with the holes at Rkm 16 and 25 in 616 the North Channel. First, a large gradient of turbidity occurs downstream of the 617 hole at Rkm 16 in the North Channel, consistent with a strong gradient in salinity 618 and landward transport. Observations of Jay et al. 2007 confirm that landward 619 transport and trapping efficiency in the $\operatorname{CRE}\left(E=C_{\max } / C_{R}\right.$; where $C_{R}=$ river 620 concentration of particles) are indeed greatest in the North Channel near Rkm 15.

621 Second, sediment trapping appears to be fixed between the topographic holes at $622 \mathrm{Rkm} 16$ and Rkm 25 for much of the greater diurnal tidal range/river flow 623 parameter space (Fig. 12 and 13). Although the surface ETM appears to persist in 624 this region, surface and bottom turbidity maximum may not be coincident (as 625 with the salinity field in the South Channel) and further research is necessary. 


\subsubsection{Trapping Efficiency}

627

Scaling and analysis of data from 15 systems (Jay et al., 2007) suggests

628 that trapping efficiency, E decreases as the supply number $S_{R}$ increases:

$$
S_{R}=\frac{U_{R}}{U_{T}} \frac{W_{s}}{\kappa U_{*}}
$$

629 where $W_{S}$ is particle settling velocity, $\mathrm{K}$ is von Karmann's constant, $U_{*}$ the shear

630 velocity, $U_{R}$ is river flow velocity, and $U_{T}$ the tidal flow velocity.

631 The Jay et al. (2007) scaling suggests that the following observations drive ETM 632 behavior in the CRE:

633

634

635

636

637

638

639

640

641

642

- For constant river flow, supply number $S_{R}$ increases and trapping efficiency $E$ decreases during small (neap) tides, since weak tidal mixing during these times fails to move sediment from the bed. Fluvial sources of sediment may then represent the maximum concentrations in the system. Our results, in which relatively large concentrations are observed in the river relative to the ETM during neap conditions, are consistent with this interpretation (e.g., Fig. 12d).

- Conversely, large (spring) tides enhance vertical mixing in the estuary, local resuspension increases, and salinity intrusion decreases due to a reduction in estuarine circulation. These factors increase $E$, decrease $S_{R}$, 
and move the ETM downstream from the fluvial source (for the same river

644 flow). Our results largely agree with this scaling (Fig. 12d).

\section{$645 \quad 4.0$ Conclusions}

646

In this study MODIS-based surface reflectance measurements and in situ

647 data were used to gain further insight into surface turbidity distributions and

648 transport processes in the CRE. Because MODIS data are synoptic and span a

649 considerable time frame ( $\sim 15$ years), a "big data" approach yields spatial and

650 temporal insights not easily available from either in situ measurements or field

651 cruises. More than 1,500 images were used to develop a climatology of turbidity

652 in the estuary and to quantitatively explore the processes that drive ETM

653 behavior. Analyses of these images highlight the following conclusions:

654 1) Surface turbidity variations in the estuary are most strongly correlated with

655 river flow; thus, monthly averaged concentrations are greatest during the

656 winter months when river flows from turbid, coastal tributaries are

657 maximum. Elevated turbidity persists, however, during the spring freshet

658 in the mainstem Columbia, and annual minimum turbidity levels are

659 observed during late summer. Greater diurnal tidal range controls surface

660 turbidity concentrations to second order. As a result SSC is maximal and

661 the ETM most prominent during spring tides when tidal currents and 662 vertical mixing are elevated. 
663 2) The synoptic nature of satellite data reveals two turbidity maxima in the 664 CRE-one in the North Channel and one in the South Channel-with 665 different responses to external forcing. Both ETM increase in magnitude 666 with increasing river flow and tidal range. However, while the North 667 Channel ETM location is relatively stable over the observed range of river 668 flow and tidal range, the South Channel ETM migrates sea/landward about $66920 \mathrm{~km}$ with increasing/decreasing river flow and tidal range.

670 3) Although turbidity levels fluctuate during the year, the spatial distribution 671 is more consistent, and large gradients are often observed in the 672 673 mid/lower-estuary. MODIS-based turbidity transects also validate the theoretical expectation that ETM are inherently asymmetric. Because the distribution of sediment downstream of the ETM location $\left(X_{\max }\right)$ scales with salinity intrusion, and upstream of $X_{\max }$ with river discharge, an asymmetric profile can develop. In the CRE, turbidity gradients seaward of the ETM can reach twice those upstream of the ETM during large river flows and tidal ranges.

4) While large river flows and greater diurnal tidal ranges prompt seaward migration of the ETM, topographic trapping in mid-estuary near local depth maxima limits further downstream movement. Because internal asymmetry and gravitational circulation increase nonlinearly with water 
683 depth, they provide a mechanism for limiting ETM movement at this 684 location.

685 These results highlight a fundamental characteristic of the CRE-since ETM 686 are not observed seaward of topographic lows in the mid/lower-estuary, and 687 since asymmetry in the turbidity distribution increases as $X_{\max }$ approaches this 688 region from upstream, bottom topography is likely an essential component 689 contributing to sediment transport and ETM formation. Indeed, maximal values of 690 trapping efficiency (E) occur in the North Channel at Rkm 15, near a local 691 depression in the bed (Jay et al., 2007). Topographic trapping of ETM has also 692 been observed in other estuaries (Roberts and Pierce, 1976; Schoellhammer, 693 2001; Ralston et al., 2012) and is therefore fundamental to the sediment 694 dynamics in many estuarine systems-especially those with strong baroclinic 695 gradients that drive depth-sensitive circulation. Despite considerable stratification 696 in the mid/lower-estuary (Fig. 12; Fig. 14), our measurements indicate that 697 surface signatures of topographic trapping can be observed with satellite data. 


\section{Acknowledgements}

699 This work was supported by the Office of Naval Research under award N00014-

700 13-1-0084 and the National Science Foundation, Award number 1455350. We thank

701 USGS, NOAA, NASA, and CMOP personnel for making their data available.

702

\section{References}

704 Allen, G.P., J. C. Salomon, P. Bassoullet, Y. Du Phenhoat, C. De Grandpré. 1980.

705 Effects of tides on mixing and suspended sediment transport in macrotidal 706 estuaries. Sedimentary Geology 26: 69-90.

707

708 Balster, C. A. and R. B. Parsons. 1968. Geomorphology and soils Willamette 709 Valley, Oregon. Soil Conservation Service, Special Report 265.

710

711 Benner, Patricia A. and James R. Sedell. 1997. Upper Willamette River landscape:

712 A historic perspective. In River quality: dynamics and resotoration, ed. Antonius 713 Laenen and David A. Dunnette, 23-47. New York: CRC Press.

714

715 Bricaud, Annick, André Morel, Louis Prieur. 1981. Absorption by dissolved 716 organic matter of the sea (yellow substance) in the UV and visible domains. 717 Limonl. Oceaonogr. 26: 43-53.

718

719 Bricaud, Annick, Marcel Babin, André Morel, Herve Claustre. 1995. Variability in 720 the chlorophyll-specific absorption coefficients of natural phytoplankton: Analysis 721 and parameterization. Journal of Geophysical Research, 100(C7): 13,321-13,332. 722

723 Burchard, H. and H. Baumert. 1998. The formation of estuarine turbidity maxima 724 due to density effects in the salt wedge. A hydrodynamic process study. Journal of 725 Physical Oceanography 28(2): 309-321. 
727 Burchard, H., H. Schuttelaars, W. Geyer. 2013. Residual sediment fluxes in 728 weakly-to-periodically stratified estuaries and tidal inlets. Journal of Physical 729 Oceanography 43(9): 1841-1861.

730

731 Chawla, Arun, David A. Jay, Antonio M. Baptista, Michael Wilkin. Charles Seaton.

732 2007. Seasonal variability and estuary-shelf interactions in circulation dynamics 733 of a river-dominated estuary. Estuaries and Coasts 31(2): 269-288. doi: 734 10.1007/s12237-007-9022-7.

735

736 Chen, Zhiqiang, Chuamin Hu, Frank Muller-Karger. 2006. Monitoring turbidity in 737 Tampa Bay using MODIS/Aqua 250-m imagery. Remote Sensing of Environment 738 109: 207-220.

739

740 Chernetsky, A.S., H.M. Schuttelaars, S.A. Talke, 2010. The effect of tidal 741 asymmetry and temporal settling lag on sediment trapping in tidal estuaries. 742 Ocean Dynamics 60: 1219-1241. doi: 10.1007/s10236-010-0329-8

743

744 Christie, M.C., K.R. Dyer, P. Turner. 1999. Sediment flux and bed level 745 measurements from a macro tidal mudflat. Estuarine, Coastal and Shelf Science 746 49: 667-688.

747

748 Donker, Jasper J. A. and Huib de Swart. 2013. Effects of bottom slope, 749 flocculation and hindered settling on the coupled dynamics of currents and 750 suspended sediment in highly turbid estuaries, a simple model. Ocean Dynamics 751 63: 311-327.

752

753 Doxaran, David, Jean-Marie Friodefond, Patrice Castaing. 2003. Remote-sensing 754 reflectance of turbid sediment-dominated waters. Reduction of sediment type 
755 variations and changing illumination conditions effects by the use of reflectance 756 ratios. Applied Optics 42: 2623-2634.

757

758 Doxaran, David, Patrice Castaing, S.J. Lavender. 2006. Monitoring the maximum

759 turbidity zone and detecting fine-scale turbidity features in the Gironde estuary 760 using high spatial resolution satellite sensor (SPOT HRV, Landsat ETM+) data.

761 International Journal of Remote Sensing 27: 2303-2321.

762

763 Doxaran, David, Jean-Marie Friodefond, Patric Castaing, Marcel Babin. 2009.

764 Dynamics of the turbidity maximum zone in a macrotidal estuary (the Gironde, 765 France): Observations from field and MODIS satellite data. Estuarine, Coastal and 766 Shelf Science 81: 321-332. doi: 10.1016/j.ecss.2008.11.013.

767

768 Elias, E. P. L., G. Gelfenbaum, A. J. Van der Westhuysen. 2012. Validation of a 769 coupled wave-flow model in a high-energy setting: The mouth of the Columbia 770 River. Journal of Geophysical Research 117: C09011. doi: $771 \quad 10.1029 / 2012 J C 008105$.

772

773 Fain, Annika M. V., David A. Jay, Doug J. Wilson, Phil M. Orton, Antonio M. 774 Baptista. 2001. Seasonal and tidal monthly patterns of particulate matter 775 dynamics in the Columbia River Estuary. Estuaries 24: 770-786.

776

777 Festa, John F. and Donald V. Hansen. 1978. Turbidity maxima in partially mixed 778 estuaries: A two-dimensional numerical model. Estuarine and Coastal Marine 779 Science 7: 347-359

780

781 Gates, Edward Breed. 1994. The holocene sedimentary framework of the lower 782 Columbia River basin. Masters thesis, Portland State University. 783 
784 Gelfenbaum, Guy. 1983. Suspended-sediment response to semidiurnal and 785 fortnightly tidal variations in a mesotidal estuary: Columbia River, USA. Marine 786 Geology 52: 39-57.

787

788 Geyer, W. Rockwell. 1993. The importance of suppression of turbulence by 789 stratification on the estuarine turbidity maximum. Estuaries 16: 113-125.

790

791 Geyer, W. Rockwell, Jonathan D. Woodruff, Peter Traykovski. 2001. Sediment 792 transport and trapping in the the Hudson River Estuary. Estuaries 24(5): 670-679. 793

794 Hansen, D. V. and M. Rattray, Jr. 1965. Gravitational circulation in straits and 795 estuaries. J. Mar. Res. 23: 104-122.

796

797 Hickey, B. M., R.M. Kudela, J.D. Nash, K. W. Bruland, W. T. Peterson, P. 798 MacCready, E. J. Lessard, D. A. Jay, N. S. Banas, A. M. Baptista, E. P. Dever, P. M. 799 Kosro, L. K. Kilcher, A. R. Horner-Devine, E. D. Zaron, R. M. McCabe, J. O. 800 Peterson, P. M. Orton, J. Pan, M. C. Lohan. 2010. River Influences on Shelf 801 Ecosystems: Introduction and synthesis. Journal of Geophysical Research 115: 802 C00B17. doi: 10.1029/2009JC5452

803

804 Hickson, R. E. and F. W. Rodolf. 1950. History of Columbia River jetties. In 805 Proceedings of the first conference on coastal engineering, ed. J. W. Johnson, 283806298.

807

808 Horner-Devine, Alexander R., David A. Jay, Phillip M. Orton, Emily Y. Spahn. 809 2009. A conceptual model of the strongly tidal Columbia River plume. Journal of 810 Marine Systems 78: 460-475. doi: 10.1016/j.jmarsys.2008.11.025 
812 Hu, Chuanmin., Zhiqiang Chen, Tonya D. Clayton, Peter Swarzenski, John C.

813 Brock, Frank E. Juller Karger. 2004. Assessment of estuarine water-quality 814 indicators using MODIS medium-resolution bands: Initial results from Tampa 815 Bay, FL. Remote Sensing of Environment 93: 423-441. doi: $816 \quad 10.1016 /$ j.res.2004.08.007.

817

818 Hughes, F. W. and M. Rattray Jr. 1980. Salt flux and mixing in the Columbia 819 River Estuary. Estuarine and Coastal Marine Science 10: 479-493.

820

821 IOCCG, 2006, Remote Sensing of Inherent Optical Properties: Fundamentals, 822 Tests of Algorithms, and Applications. Lee, Z.-P. (ed.), Reports of the 823 International Ocean-Colour Coordinating Group, No. 5, IOCCG, Dartmouth, 824 Canada.

825

826 Jay, David A. 1991. Green's Law Revisited: Tidal long-wave propagation in 827 channels with strong topography. Journal of Geophysical Research 96(C11): $82820,585-20,598$.

829

830 Jay, David A., Benjamin S. Giese, Christopher R. Sherwood. 1990. Energetics and 831 sedimentary processes in the Columbia River Estuary. Progress in Oceanography 832 25: 157-174.

833

834 Jay, David A. and J. Dungan Smith. 1990a. Circulation, density distribution and 835 neap-spring transitions in the Columbia River Estuary. Progress in Oceanography 836 25: 81-112.

837

838 Jay, David A. and J. Dungan Smith. 1990b. Residual circulation in shallow 839 estuaries 1. highly stratified, narrow estuaries. Journal of Geophysical Research 840 95(C1): 711-731. 
842 Jay, David A., Jeffery D. Musiak. 1994. Particle Trapping in estuarine tidal flows.

843 Journal of Geophysical Research 99(C10): 20,445-20,461.

844

845 Jay, David A., Jeffery D. Musiak. 1996. Internal tidal asymmetry in channel flows:

846 Origins and consequences. Coastal and Estuarine Studies 50: 211-249.

847

849 Jay, David A., Phillip M. Orton, David J. Kay, Annika Fain, Antonio M. Baptista.

850 1999. Acoustic determination of sediment concentrations, settling velocities,

851 horizontal transports and vertical fluxes in estuaries. Porceedings of the IEEE

852 Sixth Working Conference: 258-263.

853

854 Jay, David A., Phillip M. Orton, Thomas Chisholm, Douglas J. Wilson, Annika M.

855 V. Fain. 2007. Particle trapping in stratified estuaries: application to observations.

856 Estuaries and Coasts 30(6): 1106-1125.

857

858 Jay, D. A., S. A. Talke, A. Hudson, M. Twardowski. 2015. Estuarine turbidity 859 maxima revisited: Instrumental approaches, remote sensing, modeling studies, 860 and new directions. In Developments in Sedimentology: Fluvial-Tidal 861 Sedimentology, eds. Philip J. Ashworth, James L. Best, and Daniel R. Parsons, 49862 109: Elsevier.

863

864 de Jonge, V.N., J.E.E. van Beusekom. 1995. Wind and tide induced resuspension 865 of sediment and microphytobenthos from tidal flats in the Ems estuary. Limnology 866 and Oceanography 40: 766-778.

867

868 de Jonge, V.N., Henk M. Schuttelaars, Justus E.E. van Beusekom, Stefan A. Talke, 869 Huib E. de Swart. 2014. The influence of channel deepening on estuarine 
870 turbidity levels and dynamics, as exemplified by the Ems estuary. Estuarine, 871 Coastal and Shelf Science 139: 46-59.

872

873 Kappenberg, Jens and Iris Grabemann. 2001. Variability of the mixing zones and 874 estuarine turbidity maxima in the Elbe and Weser Estuaries. Estuaries 5: 699-706. 875

876 Lehner, Susanne, Ivonne Anders, Gerhard Gayer. 2004. High resolution maps of 877 suspended particulate matter concentration in the Geman Bight. EARSeL 878 eProceedings 3: 118-126.

879

880 Lyons, Joseph K. and Robert L. Beschta. 1983. Land use, floods, and channel 881 changes: Upper Middle Fork Willamette River, Oregon (1936-1980). Water 882 Resources Research 19(2): 463-471.

883

884 Maritorena, Stéphane, David A. Siegel, Alan R. Peterson. 2002. Optimization of 885 semianalytical ocean color model for global-scale applications. Applied Optics 886 41(15): 2705-2714.

887

888 May, C. L., J. R. Koseff, L. V. Lucas, J. E. Cloern, D. H. Schoellhamer. 2003. Effects 889 of spatial and temporal variability of turbidity on phytoplankton blooms. Marine 890 Ecology Progress Series 254: 111-128.

891

892 Meade, Robert H. 1969. Landward transport of bottom sediments in estuaries of 893 the Atlantic coastal plain. Journal of Sedimentary Research 39(1): 222-234 894

896 Naik, Pradeep K. and David A. Jay. 2010. Human and climate impacts on 897 Columbia River hydrology and salmonids. River Research and Applications 27: 898 1270-1276. doi: 10.1002/rra.1422. 
901 Naik, Pradeep K. and David A. Jay. 2011. Distinguishing human and climate 902 influences on the Columbia River: Changes in mean flow and sediment transport. 903 Journal of Hydrology 404: 259-277. doi: 10.1016/j.jhydrol.2001.04.035.

904

905 Naiman, Robert J., Timothy J. Beechie, Lee E. Benda, Dean R. Berg, Peter A. 906 Bison, Lee H. MacDonald, Matthew D. O'Connor, Patricia L. Olson, E. Ashley 907 Steel. 1992. Fundamental elements of ecologically healthy watersheds in the 908 pacific northwest coastal ecoregion. In Watershed Management: Balancing 909 Sustainability with Environment Change, ed. R.J. Naiman, 127-188. New York: 910 Springer-Verlag.

911

912 Neukermans, G., H. Liosel, X. Meriaux, R. Astoreca, D. McKee. 2012. In situ 913 variability of mass-specific beam attenuation and backscattering of marine 914 particles with respect to particle size, density, and composition. Limnology and 915 Oceanography 57(1): 124-144.

916

917 Norman, David K., C. Jeff Cederholm, William S. Lingley Jr. 1998. Flood plains, 918 salmon habitat, and sand and gravel mining. Washington Geology 26(2): 1-28. 919

920 Orem, Hollis M. 1968. Discharge in the lower Columbia River basin, 1928-65. 921 U.S. Geological Survey Circular 550.

922

923 Palacios, L. Sherry., Tawnya D. Peterson, Raphael M. Kudela. 2009. Development 924 of synthetic salinity from remote sensing for the Columbia River Plume. Journal of 925 Geophysical Research 114: C00B05. doi: 10.1029/2008JC004895. 
927 Postma, H. and K. Kalle. 1955. Die Entstehung von Trübungszonen im Unterlauf 928 der Flüsse, speziell im Hinblick auf die Verhältnisse in der Unterelbe. Deutsche 929 Hydrografische Zeitschrift 8(4): 134-144.

930

931 Pruter, A.T. and D.L. Alverson. 1972. The Columbia River Estuary and adjacent 932 ocean waters. Seattle: University of Washington Press.

933

934 Ralston, David K., W. Rockwell Geyer, John C. Warner. 2012. Bathymetric 935 controls on sediment transport in the Hudson River estuary: Lateral asymmetry 936 and frontal trapping. Journal of Geophysical Research 117: C10013. doi: $937 \quad 10.1029 / 2012 J C 008124$

938

939 Reed, D. J. and J. Donovan. 1994. The character and composition of the Columbia 940 River estuarine turbidity maximum. In Changes in fluxes in estuaries: Implications 941 from science to management, eds. K. R. Dyer and Robert J. Orth, 445-450. 942 Fredensborg, Denmark: Olsen and Olsen.

943

944 Roberts, W. P., J. W. Pierce. 1976. Deposition in Upper Patuxent Estuary, 945 Maryland, 1968-1969. Estuarine and Coastal Marine Science 4: 267-280. 946

947 Ruhl C. A., D. H. Schoellhamer, R. P. Stumpf, C. L. Lindsay. 2001. Combined use 948 of remote sensing and continuous monitoring to analyse the variability of 949 suspended-sediment concentrations in San Fransisco bay, California. Estuarine, 950 Coastal, and Shelf Science 53: 801-812.

951

952 Schoellhamer, D. H. 2001. Influence of salinity, bottom topography, and tides on 953 locations of estuarine turbidity maxima in northern San Fransisco Bay. In Coastal 954 and Estuarine Fine Sediment Transport Processes, ed. McAnally, W.H., and 955 Mehta, A.J., 343-357. Elsevier Science B.V. 
957 Sherwood, Christopher R., David A. Jay, R. Bradford Harvey, Peter Hamilton, 958 Charles A. Simenstad. 1990. Historical changes in the Columbia River Estuary. 959 Progress in Oceanography 25: 299-352.

960

961 Sherwood, Christopher R. and Joe S. Craeger. 1990. Sedimentary geology of the 962 Columbia River Estuary. Progress in Oceanography 25: 15-79.

963

964 Simenstad, Charles A., Lawrence F. Small, C. David McIntire. 1990. Consumption 965 processes and food web structure in the Columbia River Estuary. Progress in 966 Oceanography 25: 271-297.

967

968 Simenstad, Charles A., Lawrence F. Small, C. David McIntire, David A. Jay, 969 Christopher Sherwood. 1990. Columbia River Estuary studies: An introduction to 970 the estuary, a brief history, and prior studies. Progress in Oceanography 25: 1-13. 971

972 Simpson, J. H., J. Brown, J. Matthes, G. Allen. 1990. Tidal straining, density 973 currents, and stirring in the control of estuarine stratification. Estuaries: 13(2) 974 125-132.

975

976 Spahn, Emily Y., Alexander R. Horner-Devine, Jonathan D. Nash, David A. Jay, 977 Levi Kilcher. 2009. Particle resuspension in the Columbia River plume near field. 978 Journal of Geophysical Research: Oceans 114(C2).

979

980 Stevenson, J. Court, Michael S. Kearney, Edward C. Pendleton. 1985. 981 Sedimentation and erosion in a Chesapeake Bay brackish marsh system. Marine 982 Geology 67(3): 213-235. 
984 de Swart, H. E., H. M. Schuttelaars, S. A. Talke. 2009. Initial growth of 985 phytoplankton in turbid estuaries: A simple model. Continental Shelf Research 986 29(1): 136-147.

987

988 Talke, S.A., H.E. de Swart, and H.M. Schuttelaars, 2008. An analytical model of 989 the equilibrium distribution of suspended sediment in an estuary. In Dohmen990 Janssen and Hulscher, eds: River, Coastal and Estuarine Morphodynamics 2008, p. 991 403-411, London, Taylor and Francis.

992

993 Talke, S.A., H.E. de Swart, V.N. de Jonge. 2009a. An idealized model and 994 systematic process study of oxygen depletion in highly turbid estuaries. Estuaries 995 and Coasts 32(4): 602-620.

996

997 Talke, S.A, H.E. De Swart and H.M.Schuttelaars. 2009b. Feedback between 998 residual circulation and sediment distribution in highly turbid estuaries: an 999 analytical model. Continental Shelf Research 29(1): 119-135. doi: $1000 \quad 10.1016 /$ j.csr.2007.09.002

1001

1002 Talke, S.A. and M.T. Stacey. 2003. The influence of oceanic swell on flows over 1003 an estuarine intertidal mudflat in San Francisco Bay. Estuarine, Coastal, and Shelf 1004 Science 58: 541-554.

1005

1006 Talke, S.A. and M.T. Stacey. 2008. Suspended Sediment Fluxes at an intertidal 1007 flat: Shifting Influence of wave, wind, tidal, and freshwater forcing. Continental 1008 Shelf Research 28(6): 710-725. doi: 10.1016/j.csr.2007.12.003

1009 
1010 Templeton, William J. and David A. Jay. 2013. Lower Columbia River sand supply 1011 and removal: Estimates of two sand budget components. Journal of Waterway, 1012 Port, Coastal, and Ocean Engineering 139: 383-392.

1013

1014 Theisen, Arthur Albert. 1958. Distribution and characteristics of loess-like soil 1015 parent material in Northwestern Oregon. Masters Thesis, Oregon State College. 1016

1017 Uncles, R. J., J. A. Stephens, R. E. Smith. 2002. The dependence of estuarine 1018 turbidity on the tidal intrusion length, tidal range and residence time. Continental 1019 Shelf Research 22: 1835-1856.

1020

1021 Vermote E. F. and A. Vermeulen. 1999. MODIS algorithm technical background 1022 document, atmospheric correction algorithm: spectral reflectances (MOD09). 1023 NASA.

1024

1025 Warner, John C., W. Rockwell Geyer, James A. Lerczak. 2005. Numerical 1026 modeling of an estuary: A comprehensive skill assessment. Journal of Geophysical 1027 Research 110: C05001. doi: 10.1029/2004JC002691

1028

1029 Wentz, Denis A., Bernadine A. Bonn, Kurt D. Carpenter, Stephen R. Hinkle, Mary 1030 L. Janet, Frank A. Rinella, Mark A. Uhrich, Ian R. Waite, Antonius Laenen, 1031 Kenneth E. Bencala. 1998. Water quality in the Willamette Basin, Oregon, 19911032 95. U.S. Geological Survey Circular 1161.

1033

\section{Figure Captions}

1035 Fig. 1 The Columbia River, coastal tributaries (Cowlitz, Willamette, and Sandy), and 1036 Columbia River Estuary (inset). Columbia River flows are measured at The Dalles and 1037 Beaver Army Terminal. The lower-estuary extends from the mouth (Rkm 0) to Youngs 1038 Bay ( $\sim \mathrm{Rkm} 15)$, mid-estuary continues up to Tongue Point ( $\sim \mathrm{Rkm} 30)$, and the upper- 
1039 estuary to the landward limits of salinity intrusion ( $\sim \mathrm{Rkm} 50)$. Transects denote the two

1040 main channels (North and South) in the system. Stations measuring turbidity are denoted

1041 by square icons, those measuring salinity by circles. Grid near mouth of Columbia River

1042 represents a 10x10 MODIS Grid at 250m resolution.

1043

1044 Fig. 2 Annual hydrograph measured at Beaver Army Terminal, (the sum of all river flow 1045 entering the estuary; solid line), The Dalles (dashed line), and coastal tributaries

1046 (Willamette, and Cowlitz rivers; dash-dotted line), monthly averaged during the study 1047 period in daily intervals. Maximum river flows in the Columbia River (Dalles) are 1048 observed May-June during the spring freshet; minimum flows occur during late summer. 1049 Coastal rivers peak during winter.

1050

1051 Fig. 3 Approximate depth profiles along the North (a) and South (b) Channel of the CRE, 1052 relative to MLLW. The South Channel is maintained at a minimum depth of $13 \mathrm{~m}$ and 1053 both channels exhibit several topographic lows.

1054

1055 Fig. 4 Measurement record for turbidity sensors used in this study

1056

1057 Fig. 5 Estimates of MODIS-based turbidity vs. in situ measurements

1058

1059 Fig. 6 Example turbidity distributions in the CRE derived from MODIS-based surface 1060 reflectance. The turbidity is a function of both river flow and tidal range. The left panels 1061 are measured at a time of moderate tidal ranges $(\sim 2.6 \mathrm{~m})$ during low (a) and high (c) 1062 flow rates. Right panels illustrate neap (1.7m tidal range) and spring ( $3.5 \mathrm{~m}$ tidal range; b

1063 and d, respectively) conditions at a time of low river flow. The two plots at bottom show 1064 prominent ETM

1065

1066 Fig. 7 Monthly averaged turbidity distributions. Elevated concentrations begin during the 1067 winter months and persist throughout the spring while high river flows are maintained. 1068 Minimum concentrations occur in late summer at periods of low flow. Each plot is the 1069 average of at least 65 MODIS images 
1071 Fig. 8 Correlation map between MODIS derived turbidity and wind-speed during 1072 summer (a) and winter (b). The effect of wind speed is confined to shallow locations and 1073 is greatest in the lower estuary bays. Summer time winds affect the southern bays, 1074 whereas wintertime winds mostly affect Baker Bay in the northern estuary near the 1075 mouth.

1076

1077 Fig. 9 Correlation map between MODIS derived turbidity and ocean swell wave energy. 1078 Waves only affect turbidity near the mouth of the CRE

1079

Fig. 10 Correlation map between MODIS derived turbidity and tidal range. Tidal range is 1081 positively correlated with surface turbidity throughout the system

1083 Fig. 11 Correlation map between MODIS derived turbidity and river flow measured at 1084 Beaver Army Terminal, The Dalles, Willamette River, and Cowlitz River

1086 Fig. 12 Longitudinal transects of turbidity (solid lines) in the North (left) and South 1087 (right) Channels. Transects represent median values, binned according to greater diurnal 1088 tidal ranges (bottom; $2.5 \mathrm{~m}$ and $3 \mathrm{~m}$ with $0.15 \mathrm{~m}$ window) and river flow (top; $3000 \mathrm{~m}^{3} \mathrm{~s}^{-1}$ 1089 and $11000 \mathrm{~m}^{3} \mathrm{~s}^{-1}$ with $500 \mathrm{~m}^{3} \mathrm{~s}^{-1}$ window). Shaded regions denote $33^{\text {rd }}$ and $67^{\text {th }}$ quantiles of 1090 binned transects. Near surface and near bed salinity intrusion (dotted and dashed 1091 lines,respectively) and 2 psu contours (squares and circles, respectively) have paired 1092 response with turbidity distribution to forcing data.

1094 Fig. 13 The location $\left(\mathrm{X}_{\max }\right)$ and magnitude $\left(\mathrm{C}_{\max }\right)$ of the ETM in the North (left) and 1095 South (right) Channel plotted in the river flow and tidal range parameter space. 1096 Increasing river flow and tidal range promote seaward advection and greater intensity of 1097 the ETM

1098

1099 Fig. 14 Daily averaged stratification in the North (top) and South (bottom) Channel. At 1100 Rkm 16 stratification in the North Channel decreases with tidal range (right) and river 
1101 flow (left). At Rkm 28 stratification in the South Channel decreases with freshwater 1102 discharge but depends little on tidal range

1103 


\section{Tables}

1105

Table 1. Locations of in situ turbidity measurements used in OLS

\begin{tabular}{|c|c|c|c|}
\hline Buoy & $\begin{array}{c}\text { Measurement Depth } \\
\text { (meters) }\end{array}$ & $\begin{array}{c}\text { Latitude } \\
\text { (degrees) }\end{array}$ & $\begin{array}{c}\text { Longitude } \\
\text { (degrees) }\end{array}$ \\
\hline Saturn 01 & a & 46.235 & -123.872 \\
\hline Saturn 02 & $0-1$ & 46.173 & -124.127 \\
\hline Saturn 05 & 2.5 & 46.184 & -123.188 \\
\hline Saturn 07 & 1 & 46.287 & -124.016 \\
\hline Saturn 09 & 0.5 & 46.177 & -123.869 \\
\hline
\end{tabular}

1106 a Measurements taken as an average over top 2 meters of water column 
Table 2. Locations of in situ measurements used to derive salinity intrusion and stratification.

\begin{tabular}{|c|c|c|c|c|}
\hline Buoy & $\begin{array}{c}\text { Measurement } \\
\text { Depth (meters) }\end{array}$ & $\begin{array}{c}\text { Latitude } \\
\text { (degrees) }\end{array}$ & $\begin{array}{c}\text { Longitude } \\
\text { (degrees) }\end{array}$ & $\begin{array}{c}\text { Distance from } \\
\text { mouth (km) }\end{array}$ \\
\hline SANDS & 7.9 & 46.256 & -123.982 & 7 \\
\hline DESD & 7.3 & 46.226 & -123.955 & 11 \\
\hline RED26 & 3.3 & 46.208 & -123.951 & 12 \\
\hline TANSY & 8.4 & 46.189 & -123.919 & 15 \\
\hline Saturn 01 & 7.4 & 46.235 & -123.872 & 16 \\
\hline MBS & 2.6 & 46.196 & -123.852 & 20 \\
\hline COAOF & 2.1 or 3.2 & 46.205 & -123.774 & 29 \\
\hline Saturn 04 & 8.6 & 46.204 & -123.759 & 30 \\
\hline CBNC & 6.5 & 46.210 & -123.714 & 34 \\
\hline
\end{tabular}

1109

Table 3. Measurement details of forcing parameters used in the analysis.

\begin{tabular}{|c|c|}
\hline Forcing & Measurement Location \\
\hline $\begin{array}{c}\text { Wind Speed/Direction } \\
\left(\mathrm{ms}^{-1} / \text { degrees }\right)\end{array}$ & NCDC (NOAA) Station 94224. Astoria Airport \\
\hline Wave Energy $\left(\mathrm{m}^{2} \mathrm{~Hz}^{-1}\right)$ & NBDC (NOAA) Station 46029. Columbia River Bar \\
\hline Tidal Range/Elevation (m) & NOAA Station 9439040. Astoria, OR \\
\hline $\begin{array}{c}\text { River Flow } \\
\left(\mathrm{m}^{3} \mathrm{~s}^{-1}\right)\end{array}$ & $\begin{array}{c}\text { USGS 14246900. Columbia River. Beaver Army Terminal } \\
\text { USGS 14243000. Cowlitz River. Castle Rock, WA }\end{array}$ \\
& USGS 14211720. Willamette River. Portland, OR \\
USGS 14105700. Columbia River. The Dalles, OR \\
\hline
\end{tabular}

1111

1112

1113

1114

1115

1116

1117

1118

Table 4. Model statistics for OLS between Band1 and in situ turbidity and coefficient estimates. Confidence intervals $(\alpha=0.05)$ for coefficients are provided in brackets.

\begin{tabular}{|c|l|c|c|}
\hline \multicolumn{4}{|c|}{ MODEL STATISTICS } \\
\hline Sample size & $\mathrm{R}^{2}$ & $\mathrm{P}_{\text {value }}$ & Error variance \\
\hline 205 & 0.85 & 0 & $1.25 \mathrm{ntu}$ \\
\hline \multicolumn{3}{|c|}{ COEFFICIENT ESTIMATES } \\
\hline Intercept & \multicolumn{2}{c|}{ Slope } \\
\hline $0.59[0.38 ; 0.80]$ & $13729 ; 145]$ \\
\hline
\end{tabular}

Table 5. Turbidity gradient length scales donwstream and upstream of the ETM in the North and South Channels during high river flows (Figure 12a and b). ${ }^{1}$ Length scales are estimated by fitting hyperbolic tangent curve to turbidity upstream and downstream of the ETM.

\begin{tabular}{|c|c|c|}
\hline & Downstream of ETM & Upstream of ETM \\
\hline North Channel & $11.6 \mathrm{~km}$ & $42.3 \mathrm{~km}$ \\
\hline South Channel & $11.8 \mathrm{~km}$ & $55.7 \mathrm{~km}$ \\
\hline
\end{tabular}


1119

$1120{ }^{1}$. Length scales are estimated by fitting hyperbolic tangent curve to turbidity upstream and 1121 downstream of the ETM. 